ISSN:2656-4270 (Online) 1410-4466 (Print) Accredited by Ministry of Research, Technology, and Higher Education with the ranking of Sinta (S4) SK NO.28/E/KPT/2019, 26th September 2019
Buletin Penelitian Sosial Ekonomi Pertanian Fakultas Pertanian Universitas Haluoleo

2020:22(2):95-100

http://ojs.uho.ac.id/index.php/sosek

doi: http://dx.doi.org/10.37149/sosek.v22i2.14243

\title{
ANALYSIS OF BUSINESS FEASIBILITY OF VEGETABLE TRADERS IN KENDARI CITY
}

\author{
Fahria Nadiryati Sadimantara ${ }^{\left.{ }^{*}\right)}$, Ilma Sarimustaqiyma Rianse ${ }^{1)}$, Syahrir ${ }^{1)}$ \\ ${ }^{1}$ Department of Agribusiness, Faculty of Agriculture, Halu Oleo University Kendari 93232 \\ ${ }^{*}$ Corresponding author: fahria.sadimantara@uho.ac.id
}

To cite this article:

Sadimantara, F., Rianse, I., \& Syahrir, S. (2021). Analysis of Business Feasibility of Vegetable Traders In Kendari City. Buletin Penelitian Sosial Ekonomi Pertanian Fakultas Pertanian Universitas Haluoleo, 22(2), 95 - 100. doi:http://dx.doi.org/10.37149/bpsosek.v22i2.14243

Received: September 22, 2020; Accepted: January 25, 2021; Published: January 29, 2020

\begin{abstract}
The objectives of this research are to analyze the business feasibility of traveling vegetable traders in Kendari City. Determination of research respondents in traveling vegetable traders conducted by accidental sampling. The determination method found as many as 30 traveling vegetable traders were used as a sample. The data analysis method uses income analysis and the $\mathrm{R} / \mathrm{C}$ ratio. The results showed that (1) the average income of traveling vegetable traders was Rp81.191/day and Rp9.021,22/hour. (2) the average R/C ratio of the traveling vegetable traders is 1,43 , greater than 1 . It is concluded that the business of the traveling vegetable traders in Kendari City is worth continuing.
\end{abstract}

Keywords: business feasibility; Kendari City; vegetable traders

\section{INTRODUCTION}

Indonesia is a country with population growth that continues to increase every year. Indonesia's population has reached 266.91 million people, with a dependency ratio of Indonesia's population reaching $45.56 \%$ (BPS, 2019). The development of the Indonesian people, which continues to increase, affects the increasing need for food for the community. In addition to staple food, vegetables are foodstuffs that must be fulfilled, and this fulfillment includes increasing market demand.

Meeting the community's vegetable needs is highly dependent on the amount of production that each region can produce in Southeast Sulawesi Province. With the development of vegetable production in Southeast Sulawesi Province, it can be seen that some vegetable production experienced a drastic decline in 2017. These vegetables are shallots, spinach, green beans, large chilies, cayenne pepper, long beans, water spinach, cucumber, chayote, and melons equally -the decline in production was $71.76 \%$. However, in 2018 , several vegetable productions increased again, namely leeks, shallots, spinach, cayenne pepper, long beans, kale, cauliflower, cucumber, chayote, melons, eggplant, and tomatoes, with an average production increase of 37.52 . \%.

Vegetable consumption is one of the essential factors that can affect vegetable production in Southeast Sulawesi province. The level of vegetable consumption by the population of Southeast Sulawesi Province in 2013-2015 increased by 7.71\%. However, in 2016-2018, the level of vegetable consumption decreased by $13.93 \%$ (BPS Sulawesi Tenggara, 2019). The low level of consumption could be due to several things, namely awareness of the importance of consuming vegetables and economic conditions that cause a household only to consume vegetables in a small amount. This is because the price of vegetables is relatively high and volatile.

Kendari City is the capital of Southeast Sulawesi. Kendari city has 370,728 people with an average population growth of $3.42 \%$ (BPS Kota Kendari, 2017). This makes Kendari City one of the centers for permanent and mobile vegetable trade. Several areas have become centers of vegetable trade in Kendari City, Southeast Sulawesi, including Baruga, Wua-Wua, Mandonga, Kendari, and Poasia districts. Mobile vegetable traders buy merchandise to be sold from the market or buy directly from farmers, then sell it around to homes. Some travel around to fill home shopping stalls and visit 
customers (Wahjuni 2016). Mobile vegetable traders in Kendari City see their customers from morning to evening. However, with rising prices, vegetable traders also feel the consequences of price fluctuations in the market, which affect cost performance and income performance received by mobile vegetable traders. So researchers are interested in researching with the title "Analysis of the Feasibility of a Mobile Vegetable Trader in Kendari City."

This study aimed to analyze the feasibility of a mobile vegetable trader in Kendari based on business profits. It is hoped that this research can become material for information and consideration to increase profits and improve the marketing system to provide better income for mobile vegetable traders in Kendari City.

\section{MATERIALS AND METHODS}

This research was conducted from December 2019 to July 2020 in Kendari City, Southeast Sulawesi Province. The population in this study were mobile vegetable traders who sell in Kendari City. The sample determination of the mobile vegetable traders was carried out using an accidental sampling technique, with the number of samples to be studied was 30 people. The data analysis technique used to answer the objectives in this study is to use income analysis and R / C ratio. Income analysis according to (Purwaningsih 2017) with the following formula:

$$
\begin{aligned}
T C & =T F C+T V C \\
T R & =P \cdot Q \\
I & =T R-T C
\end{aligned}
$$

Where, TC: Total cost (total cost), TFC: Total fixed cost (all costs for fixed inputs), TVC: Total variable cost (all costs for the variable input used, TR: Total revenue (total revenue), P: Sales price, Q: Number of products sold, I: Income, and R/C Ratio analysis according to (Rianse and Abdi 2008) with the following formula:

$$
\mathrm{R} / \mathrm{C} \text { Ratio }=(\mathrm{TR}) /(\mathrm{TC})
$$
revenue)

Where R/C Ratio: Return cost ratio, TC: Total cost (total cost), TR: Total revenue (total

\section{RESULTS AND DISCUSSION}

\section{Respondent Characteristics}

Characteristics of respondents observed in this study include age, education level, number of family dependents, and trading experience.

Table 1. Respondents distribution of mobile vegetable traders according to age, education level, number of family dependents, trading experience.

\begin{tabular}{llcrr}
\hline No & Characteristics of vegetable traders & Categories & $\begin{array}{c}\text { Number } \\
(\text { people })\end{array}$ & $\begin{array}{c}\text { Percentage } \\
(\%)\end{array}$ \\
\hline 1 & Age (years) & $0-14$ & 0 & 0 \\
& & $15-54$ & 30 & 100 \\
2 & Education level & $>55$ & 0 & 0 \\
& & No school & 2 & 6,67 \\
& & Elementary School & 7 & 23,33 \\
& & Junior High School & 14 & 46,67 \\
& & Public High School & 7 & 23,33 \\
& \multirow{2}{*}{ Number of family dependents } & Bachelor & 0 & 0 \\
& & Small family & 29 & 96,67 \\
& Trading experience (years) & Big family & 1 & 3,33 \\
& & $<5$ & 21 & 70 \\
& & $5-10$ & 9 & 30 \\
\hline
\end{tabular}

Source: Primary data, processed, 2020

The age of the respondent will affect their physical ability to work and their mindset. The younger the vegetable seller will undoubtedly act the level of knowledge of the vegetable trader to 
work. Based on the analysis results (Table 1), it can be seen that all respondents who are mobile vegetable traders are of productive age. So it can be concluded that based on the age level of the vegetable traders, respondents have relatively adequate work productivity based on their age level.

The level of education referred to in this study is the level of formal education that the mobile vegetable trader respondent has passed. Education is one of the factors that can stimulate traders to be creative and innovative in solving any problems related to business in marketing agricultural products. If the trader has adequate education, the trader will think and act more rationally by considering various aspects of marketing. According to Zuhriski (2008), someone's education will make it easier to make shopping transactions at the market or sell products directly to consumers. The results of the analysis (Table 1) show that the formal education of the mobile vegetable traders respondents was not in school (6.67\%), SD (23.33\%), SMP (46.67\%), and SMA (23.33\%), respectively. . This shows that the majority of mobile vegetable traders are at the moderate level, namely junior high school.

The family dependents in question are all family members in one house or not in one place whose living expenses are borne by the vegetable trader. Family members can be a guarantee in the provision of workers who help manage the business. Family members have a considerable influence on a person's business activities because, besides being a source of labor, they also often involve family members in making decisions so that decisions are family decisions. The greater the number of family dependents, the greater the effort made by a trader in helping the family to meet their daily needs. However, if the family members are already productive enough, the addition of family members will reduce the burden on the family in overcoming household needs. Soehardjo \& Patong (1984) states that what is meant by small family members is around 1-4 people, while more than four people are prominent family members.

The results of the analysis (Table 1) show that the number of family dependents of the mobile vegetable trader respondents who are included in the small family category is 29 people $(96.67 \%)$ and one person in the large family category (3.33\%). Many dependents in the family will further motivate traders to earn more income from their business activities to fulfill their family's needs. The overall respondents who sell vegetables in Kendari City are vegetable traders who have a small number of dependents.

Trading experience can influence the pattern of thinking of vegetable traders in the activities they are engaged in. The level of their experience depends on how long it took someone to carry out the trading activity in question. Trading experience is an educational process obtained outside of school. It has an essential meaning for vegetable traders in pursuing their interests and can change vegetable traders in managing their business. The longer the experience in these activities, it is hoped that vegetable traders can learn more to make good choices or alternatives to improve their family welfare. According to Soeharjo and Patong (1984), the farming experience will be pretty experienced if you have been in the business for 5-10 years, while ten years and above are categorized as professional and less than five years are classified as less experienced.

Based on the analysis results (Table 1), it shows that the trading experience of mobile vegetable traders has an average trading experience of fewer than five years or less experience, amounting to 21 people (70\%). Thus, it can be said that the mobile vegetable traders are inexperienced and less able to make effective and skilled decisions in managing their business to boost their income. This is in line with Nafsinta's research (2019), that the more experience the respondent gets, the better it is in making effective decisions and skilled in managing the business.

\section{Cost}

The amount of income from mobile vegetable traders is strongly influenced by the income factor and costs incurred by the vegetable traders. The expenditure referred to in this study is the total value of the selling facilities used by the respondent in managing the vegetable trading business that implements a daily roundabout system. These costs include variable costs consisting of purchasing vegetables, transportation costs/selling costs, packaging costs, and consumption costs. Meanwhile, fixed prices include equipment depreciation, vegetables, vehicle tax, and rental of the place of sale. The costs incurred by respondents are generally influenced by the number of facilities used and the purchase of selling materials. The more the number of facilities used and the purchase of selling materials, the higher the cost of using them. The total variable and fixed costs will produce the total expenses used in the mobile vegetable sales business. More details can be seen in Table 2.

The analysis results (Table 2) show that the average variable cost of mobile vegetable traders is not too high. This is due to the purchase of vegetables adjusted to the vegetable traders' sales capacity and working hours. Itinerant vegetable traders limit their sales capacity more because the basket capacity is determined by weight and space. In addition, the working hours of mobile 
vegetable traders are also limited because they only sell in the morning, around six to midday, and some sell until late in the afternoon.

Table 2. The average total cost of roaming vegetable traders in Kendari City

\begin{tabular}{|c|c|c|c|}
\hline \multirow{2}{*}{ No. } & \multirow{2}{*}{ Description } & \multicolumn{2}{|c|}{ Amount } \\
\hline & & (IDR/day) & (IDR/hour) \\
\hline & Total Variable Cost (TVC) & 163.455 & $18.161,66$ \\
\hline 2. & Total Fixed Cost (TFC) & 22.112 & $2.456,89$ \\
\hline 3. & Total Cost (TC) & 185.567 & $20.618,55$ \\
\hline
\end{tabular}

Source: Primary data, processed, 2020

It can also be said that the average fixed costs of mobile vegetable traders are not too high. This is influenced by the depreciation of vegetables and taxes/rent, where the number of vegetable purchases influences the average depreciation of vegetables by vegetable traders. So that the vegetable shrinkage of the mobile vegetable traders is IDR 6,696 / day. The average tax/rental of itinerant vegetable traders is IDR 1,163 / day. This is in line with Astuti's (2018) research which states that the most significant cost incurred is the cost of purchasing vegetables which is the essential cost of doing a vegetable trading business. The costs incurred by mobile vegetable traders are relatively small, making the traders not need to prepare a lot of capital every day.

\section{Revenue}

The revenue referred to in this research is multiplying the number of vegetable sales between the prevailing prices. Most of the income earned by the vegetable traders is used to fulfill their daily needs and to continue their business. Based on the analysis results in Table 3, the average income of mobile vegetable traders in Kendari City is not too large. This is due to the working hours/time of selling the itinerant vegetable traders who only sell 9 hours/day. The size of a vegetable merchant's receipt depends on how much sales are generated.

Table 3. Average of mobile vegetable traders acceptance by type of vegetables in Kendari City

\begin{tabular}{|c|c|c|c|c|}
\hline No. & Vegetables & $\begin{array}{c}\text { Sales } \\
\text { (Kg/day) }\end{array}$ & $\begin{array}{c}\text { Price } \\
\text { (IDR/kg) }\end{array}$ & $\begin{array}{l}\text { Revenue } \\
\text { (IDR/day) }\end{array}$ \\
\hline & Water spinach & 3,39 & $10.667,00$ & $36.334,00$ \\
\hline 2. & Long beans & 3,17 & $8.904,67$ & $28.283,13$ \\
\hline 3. & Tomatoes & 4,00 & $27.133,33$ & $105.563,00$ \\
\hline & Eggplant & 1,19 & $13.383,33$ & $14.933,67$ \\
\hline & Spinach & 1,72 & $17.424,23$ & $29.540,34$ \\
\hline & Chili Rawit & 0,67 & $80.233,33$ & $52.103,33$ \\
\hline \multicolumn{3}{|c|}{ Average Sales (kg/day) } & \multicolumn{2}{|r|}{2,36} \\
\hline \multicolumn{3}{|c|}{ Average Sales (kg/hr) } & \multicolumn{2}{|c|}{0,26} \\
\hline \multicolumn{3}{|c|}{ Average Price (IDR/kg/day) } & \multicolumn{2}{|c|}{$26.290,83$} \\
\hline \multicolumn{3}{|c|}{ Average Price (IDR/kg/hour) } & \multicolumn{2}{|c|}{$2.921,20$} \\
\hline \multicolumn{3}{|c|}{ Average Revenue (IDR/day) } & \multicolumn{2}{|c|}{$266.758,00$} \\
\hline \multicolumn{3}{|c|}{ Average Revenue (IDR/hour) } & \multicolumn{2}{|c|}{$29.639,78$} \\
\hline
\end{tabular}

Source: Primary data, processed, 2020

\section{Income}

Income on total costs represents net income from the mobile vegetable business. The buying process carried out by a producer/trader will produce several goods or products to be resold. The goods or products are the number of goods to be sold, and the result is the amount of revenue for a trader/producer. So in terms of income is the amount of money received by producers for the sale of goods produced (Sukirno, 2010). The amount of income is a measure of the success of a trader in running his business. The average income of mobile vegetable traders in Kendari City, Southeast Sulawesi Province, can be seen in Table 4.

The vegetable traders' income level in this study is influenced by the number of costs incurred in running their business and the amount of revenue received by the mobile vegetable traders. These results are in line with Rahmah's (2019) research, which states that the level of education and experience positively affects the income of vegetable traders in Langsa City. Based on the results of the character analysis of respondents in this study, the level of education of vegetable traders is 
moderate, and their experience is less than ten years, so the income of the mobile vegetable traders is not much.

Table 4. Average income of mobile vegetable traders in Kendari City

\begin{tabular}{clrr}
\hline \multirow{2}{*}{ No. } & \multicolumn{2}{c}{ Vegetables } & \multicolumn{2}{c}{ Amount } \\
\cline { 3 - 4 } 1. & Total Revenue (TR) & (IDR/day) & (IDR/hour) \\
\hline 2. & Total Cost (TC) & 266.758 & $29.639,78$ \\
\hline 3. & Income (I) & 185.567 & $20.618,55$ \\
\hline
\end{tabular}

Source: Primary data, processed, 2020

However, when viewed from the short working hours, which is only 9 hours/day, we can see that the income of the mobile vegetable traders is relatively high, namely IDR 9,021.17 / hour. This means that if the working hours of the itinerant vegetable traders are increased, their daily income can also increase. Based on the research results, most respondents used the remaining time to carry out other jobs that could increase household income.

\section{R / C Ratio}

In this study, the $\mathrm{R}$ / $\mathrm{C}$ ratio was used to determine the feasibility of a mobile vegetable trader in Kendari City. Table 5 shows that the mobile vegetable trader business is feasible and viable. The $R$ I C ratio value for itinerant vegetable traders is 1.43 , which means that if the mobile vegetable trader adds a cost of IDR 100,000, it will increase the income of IDR 100,000.

This is in line with Zuhriski's (2008) research which analyzed the income of mobile vegetable traders in three regions where all $\mathrm{R} / \mathrm{C}$ ratios were more than 1 , which means that it is profitable. Likewise, Sairdama's research (2010) which analyzes the income level of mobile vegetable traders in the Nabire Regency, shows that the R / C ratio is more than one, namely 2.05, so mobile vegetable trading activities in Nabire Regency are feasible to be cultivated because it brings profit. In addition, when compared with Sihite's research (2019) which analyzes the profits of vegetable traders in the Medan City market, where the results are also in line with this study, the R / C ratio of 1.20 means that it is profitable and feasible to continue.

Table 5. Feasibility of mobile vegetable trader in Kendari City

\begin{tabular}{|c|c|c|c|}
\hline \multirow{2}{*}{ No. } & \multirow{2}{*}{ Vegetables } & \multicolumn{2}{|c|}{ Amount } \\
\hline & & (IDR/day) & (IDR/day) \\
\hline & Total Revenue (TR) & 266.758 & $29.639,78$ \\
\hline 2. & Total Cost (TC) & 185.567 & $20.618,55$ \\
\hline & R/C Ratio & 1.43 & 0.70 \\
\hline
\end{tabular}

Source: Primary data, processed, 2020

\section{CONCLUSIONS}

Based on the research and discussion results in this study, it can be concluded that the income of the mobile vegetable traders in Kendari City is IDR 81,191 per day, where the working hours are 9 hours/day so that the hourly income is IDR 9,021.17. Furthermore, based on the R / C ratio of mobile vegetable traders of 1.43 , which is greater than 1 . This shows that the mobile vegetable trader business in Kendari City is feasible to run.

\section{REFERENCES}

Astuti, R. (2018). Analisis Biaya dan Pendapatan Usaha Pedagang Sayuran di Pasar Tamin Kota Bandar Lampung.

BPS Kota Kendari. (2017). Kota Kendari Dalam Angka 2017. BPS Kota Kendari. Kendari.

BPS Sulawesi Tenggara. (2019). Provinsi Sulawesi Tenggara Dalam Angka 2019. Biro Pusat Statistik. Sulawesi Tenggara.

BPS. (2019). Pertumbuhan Ekonomi Indonesia Triwulan II-2013. Badan Pusat Statistik Republik Indonesia.

Nafsinta. (2019). Analisis Perbedaan Pendapatan Usahatani Kacang Tanah Antara Sistem Berpindah-Pindah dengan Menetap Di Desa Lalemba Kecamatan Lawa Kabupaten Muna Barat. Skripsi. 
Purwaningsih, Y. (2017). Ekonomi Pertanian Pendekatan Teori, Kebijakan, dan Penerapan, Surakarta: UNS Press.

Rahmah, R. (2019). Pengaruh Faktor Sosial Ekonomi Terhadap Pendapatan Pedagang Sayur Di Kota Langsa. Jurnal Penelitian Ekonomi Akuntansi (JENSI) 3(2): 194-207.

Rianse, U. \& Abdi (2008). Metodologi penelitian sosial dan ekonomi: teori dan aplikasi, Alfabeta.

Sairdama, S. S. (2010). Analisis tingkat pendapatan pedagang sayuran buah keliling di Distrik Nabire Barat Kabupaten Nabire. Agrikan: Jurnal Agribisnis Perikanan 3(1): 81-89.

Sihite, F. (2019). Analisis Keuntungan Usaha Pedagang Sayur Eceran (Studi Kasus Pasar Sukaramai Kota Medan), Universitas Medan Area.

Soehardjo \& Dahlan, P. (1984). Sendi-Sendi Pokok IImu Usaha Tani. Universitas Hasanudin. Ujung Pandang

Sukirno, S. (2010). Teori Pengantar Makro Ekonomi Edisi Ketiga. Raja Grafindo. Jakarta.

Wahjuni, E. (2016). Solidaritas Kaum Laki-laki Sebagai Pedagang Sayur Keliling atau Bakul Ethek di Pasar Songgo Langit Ponorogo." ARISTO 2(2): 15-24.

Zuhriski, H. (2008). Analisis Pendapatan Pedagang Sayur Keliling di Kelurhan Tegallega Kota Bogor, Skripsi. 